\title{
HÖG GENERELL TILLIT OCH LÅG TOLERANS MOT FRÄMLINGAR?
}

Karl Loxbo, Institutionen för statsvetenskap, Linnéuniversitetet E-post |karl.loxbo@lnu.se

Det antas ofta att samhällen med hög generell tillit också kännetecknas av utbredd tolerans mot människor från minoritetskulturer (Uslaner 2002). En sådan tolkning baseras på att generell tillit definitionsmässigt betyder att individer generaliserar förtroendefulla erfarenheter av mellanmänsklig interaktion till okända människor och främlingar i största allmänhet (se t.ex. Yamagishi \& Yamagishi, 1994; Putnam 2007; Newton 2001; Uslaner 2002; Stolle 2001; Rothstein 2005). I ett jämförande perspektiv framhålls Sverige regelmässigt som ett land med exceptionellt hög generell tillit och denna spridda attityd antas därför ofta vara en barriär mot den intolerans och främlingsfientlighet som sprider sig i övriga Europa (se t.ex. Delhey \& Newton 2005; Loxbo 2010a).

När vi närmare granskar antagandet om att hög tillit och tolerans går hand i hand ställs vi emellertid inför en paradox. Den generella tilliten ligger kvar på höga nivåer i Sverige samtidigt som svensk opinion - precis som opinionen i övriga europeiska länder (jfr Mudde 2010) - präglas av ganska utbredd intolerans mot främlingar (se t.ex. Demker 2012). Paradoxen består i att intolerans, enligt tidigare forskning, antas spegla

(C) 2014 Karl Loxbo. Detta är en Open Access artikel distribuerad under CC-BY-NC som innebär att du tillåter andra att använda, sprida, göra om, modifiera och bygga vidare på ditt verk, men inte att verket används i kommersiella sammanhang. http://dx.doi.org/10.15626/sj.2014201 
motsatsen till tillit, det vill säga djupgående misstro (se t.ex. Delhey m.fl. 2011 ). Den problemformulering som vägleder denna artikel är därför om det är möjligt för svenskarna att på samma gång uppge att de litar på "människor i allmänhet" och samtidigt uppvisa misstro mot människor som de upplever som främlingar. Detta övergripande problem studeras i artikeln med utgångspunkt från ett antal unika mått i den riksrepresentativa enkätundersökningen Survey 2012 (Hagevi 2014). Måtten relaterar tillit till specificerade grupper av människor och i artikeln argumenterar jag med denna utgångspunkt för att det finns anledning att kritiskt utvärdera vad tillit till "människor i allmänhet” egentligen betyder när svenska folket kryssar i enkäter. Mitt argument baseras på tidigare forskning som har visat att människor ofta upplever sig ingå i olika "föreställda gemenskaper”, som i realiteten avgör vilka grupper de litar på (Putnam 2007; Nannestad 2008; Vroome m.fl. 2013:13). För att belysa forskningsproblemet syftar artikeln till att besvara tre frågeställningar. Den första lyder enligt följande:

1. I vilken grad är generell tillit bland svenskar i själva verket ett mått på tillit till människor från närliggande kulturella sfärer?

När svenska folkets attityder har granskats i sin helhet är frågan om tillit för olika grupper är relaterat till övriga politiska attityder, som på ett övergripande plan kan sägas vara representerade av partierna i det svenska partisystemet. Därför lyder den andra frågeställningen:

2. I vilken utsträckning varierar tillit och tolerans om vi samtidigt beaktar respondenternas sympati för olika politiska partier?

För att ytterligare granska paradoxen som diskuteras ovan studerar jag också hur tillit i den svenska befolkningen, mätt i relation till specificerade grupper, påverkar attityder som istället indikerar tolerans gentemot människor från andra kulturella sfärer än den svenska. Den tredje och sista frågeställningen lyder därför:

3. I vilken grad påverkar varierande, och gruppspecifika, mått på tillit graden av tolerans för upplevda främlingar från andra kulturer?

Resterande del av artikeln är upplagd på följande sätt: I det första avsnittet diskuteras teoretiska utgångspunkter medan jag i det andra redogör för statistiska mått och metoder. I det tredje avsnittet presenteras deskriptiv statistik och fördelningen av tillitsoch toleransmåtten redogörs i relation till skiftande grupper av partisympati. I de två följande avsnitten besvaras de två frågeställningarna. I det femte och sista avsnittet rekapituleras slutsatserna och dess implikationer diskuteras. 


\section{Teori: Tillit i olika dimensioner}

En etablerad begreppslig dikotomi i samhällsvetenskapen är den mellan partikulär tillit - ingroup trust (tillit till familj, grannar etc.) - och generell tillit - outgroup trust (tillit till människor man träffar för första gången) (Delhey m.fl. 2011:791). På senare tid har emellertid flera forskare visat att distinktionen mellan partikulär och generell tillit är alltför grov (Nannestad 2008). I stället för att skilja mellan tillit till kända och okända personer, tenderar respondenter - enligt flera studier - att ta "kognitiva genvägar" och dela in människor i grupper. I linje med detta visar Wollebæk m.fl. (2012:322) att människor utvecklar tillit, eller brist på tillit, för folk i deras närområde. Denna tillitsdimension - författarna kallar den områdesbaserad tillit (community-based trust) baserar sig på generaliserade erfarenheter av människor i en begränsad geografisk kontext. Denna dimension är därför separat från generell och partikulär tillit (se också Yamagishi \& Yamagishi 1994:139), och relaterar tillit till grupper av människor.

Putnam (2007:138) kommer fram till likande resultat och drar slutsatsen att boendekontexter som präglas av etnisk mångfald, snarare än homogenitet, motverkar ömsesidig tillit och solidaritet bland boende i dessa områden (se också Ross m.fl. 2001; Kumlin \& Rothstein, 2010). I linje med sådana resultat har flera forskare argumenterat för att förståelsen av mellanmänsklig tillit bör kompletteras med ytterligare en dimension, nämligen den identitetsbaserade (indentity-based trust) (Frietag \& Bauer 2013; Vroome m.fl. 2013). Enkelt uttryckt tar denna "nya” dimension fasta på mellanmänsklig tillit som baseras på gruppidentifikation, som bygger på föreställda gemenskaper grundade på etnisk, språklig eller religiös tillhörighet (jfr Nannestad 2008). I likhet med generaliserad tillit överförs positiva eller negativa erfarenheter till okända människor, men skillnaden är att tillit, eller misstro, knyts till specifika grupper av människor i stället för individer. Återigen tar alltså människor "kognitiva genvägar" och gör distinktioner mellan grupper av människor beroende på deras etnicitet, språk och kultur.

På engelska används som nämnts ovan ofta begreppsdikotomin outgroup eller ingroup (Delhey m.fl. 2011) för att ta fasta på att tillit är beroende av närheten till respondentens upplevda identitet och gemenskap, som baseras på kultur, språk eller till och med etnicitet. För att få teoretiska verktyg för att besvara frågeställningarna i artikeln relaterar jag denna begreppsdikotomi till identitetsbaserad tillit. I detta syfte gör jag en åtskillnad mellan generell tillit och vad jag kommer att kalla ingrupps- respektive utgruppstillit. Ingruppstillit avser då känslor av tillit till människor som respondenten i fråga identifierar sig med, som upplevs dela kulturella attribut med respondenten, medan utgruppstillit i stället förstås som motsatsen, dvs. tillit till människor inte upplevs dela dessa attribut, som respondenten inte identifierar sig med. 


\section{Data och metod}

Det första och mest centrala måttet i artikeln är den brett accepterade standardfrågan för att mäta generell tillit (Stolle 2002; Nannestad 2008:414). I Survey 2012 mäts denna uppfattning om människor i allmänhet, i enlighet med tidigare forskning (Kumlin \& Rothstein 2010:73), på en 11-gradig skala där frågan formuleras på följande sätt:

Figur 1. Fråga för att mäta generell tillit i Survey 2012.

Enligt din mening, i vilken utsträckning går det att lita på människor i allmänhet? Svara med hjälp av nedanstående skala. Kryssa i den ruta som ligger närmast din uppfattning.

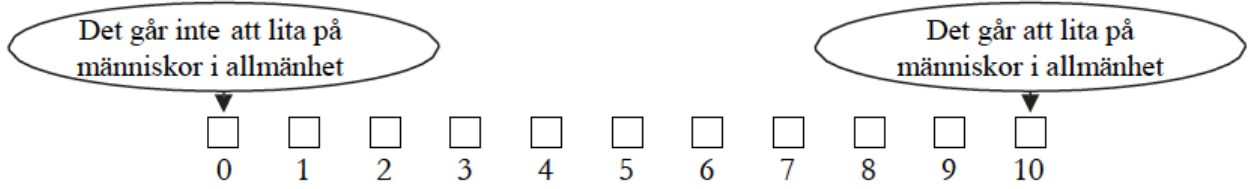

Kommentar: Medelvärdet är 5,28, medianen är 6 och standardavvikelsen är 2,32.

För att svara på frågeställningarna kontrasteras sedan detta standardmått mot sju mått som i Survey 2012 har skräddarsytts för att mäta tillit till olika grupper. Portalfrågan för sju efterföljande frågor som rör specificerade grupper med människor formuleras på följande sätt:

Figur 2. Portalfråga för sju efterföljande frågor om tillit till specificerade grupper i Survey 2012.

Enligt din mening, i vilken omfattning går det att lita på människor från följande delar av Sverige och världen? Kryssa i den ruta som ligger närmast din uppfattning.

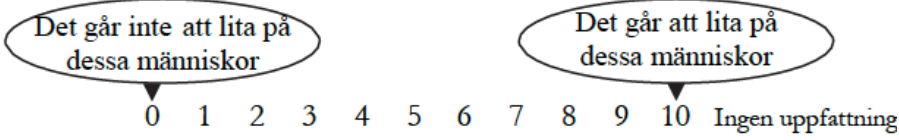

Kommentar: Svaren på de sju frågorna fördelar sig på olika sätt, sett till följande medelvärden (M), medianer (MD) och standardavvikelser (SD): Människor från den kommun där jag bor (M=7,09 MD=7 $\mathrm{SD}=2,01)$; Människor från övriga delar av Sverige (M=6,95 MD=7 SD=1,99); Människor från andra länder i Västeuropa ( $M=6,26 \mathrm{MD}=6 \mathrm{SD}=2,17)$; Människor från Östeuropa $(\mathrm{M}=4,62 \mathrm{MD}=5 \mathrm{SD}=2,64)$; Människor från Afrika (M=4,73 MD=5 SD=2,83); Människor från Mellanöstern $(\mathrm{M}=4,21 \mathrm{MD}=4$ $\mathrm{SD}=2,92)$; Människor från Latinamerika (M=5 MD=5 SD=2,65).

I linje med tidigare forskning (Nannestad 2008:417) visar redan en granskning av centralmått (se kommentar till figur 2) att nivåerna av tillit skiftar avsevärt mellan de olika grupper som frågorna avser. Det är också med utgångspunkt från dessa varierande utfall som identitetsbaserad tillit och den teoretiskt centrala dikotomin mellan utgruppen och ingruppen operationaliseras i artikeln. För att besvara artikelns första två frågeställningar studeras relationen mellan de åtta olika måtten på tillit med faktoranalys, korrelationsanalys och medelvärdesanalys. I detta syfte skapas två 
gruppspecifika index för att mäta tillit, som jag kallar utgruppstillit - de sista fyra frågorna - (Cronbachs alfa=0,952) respektive ingruppstillit - de första tre frågorna (Cronbachs alfa=0,952). När frågeställning 3 ska besvaras, med hjälp av regressionsanalys, används standardfrågan för att mäta generell tillit tillsammans med de två identitetsbaserade tillitsmåtten som tänkbara förklaringar till respondentens grad av tolerans mot främlingar.

I tidigare forskning operationaliseras ofta tolerans/intolerans mot människor från andra kulturer - ofta under samlingsbeteckningen xenofobi eller främlingsfientlighet - med utgångspunkt från frågor om hur väljare ställer sig till konkreta politiska förslag, t.ex. att minska flyktinginvandring eller att begränsa byggandet av moskéer (se t.ex. Demker 2012; Oscarsson \& Demker 2012). En lång rad forskare har därtill visat att negativa uppfattningar om invandring och människor från andra kulturer är starkt relaterade till auktoritära uppfattningar i största allmänhet - t.ex. strävan efter hårdare straff samt skepticism mot abort och jämställdhet mellan könen (se t.ex. Loxbo 2012). Denna typ av sakfrågor brukar då slås samman till index som operationaliserar den så kallade kulturella konfliktdimensionen, som löper mellan frihetliga (libertarian) och auktoritära (authoritarian) värden (se t.ex. Bornschier 2012). För att besvara frågeställningarna är dock syftet att få ett mer explicit mått på tolerans av främlingar från andra kulturer än den svenska. Tabell 1 redogör för fördelningen av fem frågor från Survey 2012, som används i syfte att mäta sådana attityder i den svenska befolkningen.

Tabell 1 visar att svenska folket uttrycker en ganska låg grad av tolerans för människor från andra kulturer, även om graden av skepticism varierar betydligt mellan frågorna. Trots variationen visar ett reliabilitetstest att frågorna i tabell 1 indikerar en och samma underliggande åsiktsdimension, vilket innebär att respondenterna tenderar att svara på likartat sätt på alla fem frågor (Cronbachs alfa=0,864). Därför slås variablerna samman (utifrån svarsmöjligheterna där "mycket bra” är kodat som 1 och "mycket dåligt” är kodat som 5) och bildar ett genomsnittligt additivt index. För att underlätta jämförelser med de tre tillitsvariablerna ges indexet samma antal skalsteg och transformeras så att den varierar mellan 0 och 10 . Skalan antas spegla ett kontinuum mellan intolerans (0) och tolerans (10) mot främlingar från andra kulturer. Indexet kallas fortsättningsvis för Främlingstolerans. För att besvara den tredje frågeställningen används indexet som beroende variabel i en linjär regressionsanalys där de huvudsakliga oberoende variablerna är de tre måtten på tillit. Den teoretiskt centrala poängen med en sådan analys är att modellen - genom att kontrastera olika mått på tillit - tillåter en granskning av huruvida svenska folket i genomsnitt kan vara tillitsfulla i vissa avseenden - t.ex. när det handlar om människor som upplevs tillhöra deras ingrupp - och samtidigt sakna tilltro till människor som snarare upplevs tillhöra utgruppen. ${ }^{1}$ 
Tabell 1. Indikatorer på tolerans för upplevda främlingar (procent).

\begin{tabular}{lccccc}
\hline & $\begin{array}{l}\text { Bra } \\
\text { förslag }\end{array}$ & $\begin{array}{c}\text { Varken } \\
\text { eller }\end{array}$ & $\begin{array}{l}\text { Dåligt } \\
\text { förslag }\end{array}$ & $\begin{array}{l}\text { Summa } \\
\text { procent }\end{array}$ & $\begin{array}{l}\text { Antal } \\
\text { svarande }\end{array}$ \\
\hline Minska antalet invandrare i Sverige & 42 & 31 & 17 & 100 & 1502 \\
Sverige bör ta emot färre flyktingar & 48 & 28 & 24 & 100 & 1503 \\
Begränsa satsningar på ett mångkulturellt samhälle $^{a}$ & 18 & 32 & 50 & 100 & 1491 \\
Begränsa invandrares möjlighet att fritt utöva sin $^{\text {religion }}{ }^{a}$ & 30 & 30 & 40 & 100 & 1501 \\
Begränsa byggandet av moskéer $^{4}$ & 47 & 29 & 24 & 100 & 1505 \\
\hline
\end{tabular}

${ }^{a}$ Svaren är omkodade så att ordningen är den omvända, och förslagen är omskrivna varianter av "satsa på ett mångkulturellt samhälle” och ”invandrare i Sverige ska fritt få utöva sin religion här”.

Som kontrollvariabler tillämpas en rad bakomliggande socio-ekonomiska faktorer, som brukar användas i studier som kartlägger varför människor uppger sig ha åsikter som forskare tolkar som främlingsfientliga. Till att börja med kontrolleras för kön, arbetarklassbakgrund, invandrarbakgrund och utbildningsnivå (jfr Oscarsson \& Demker 2012:186). Eftersom det ofta antas att främlingsfientlighet, och auktoritära värden i allmänhet, samvarierar med misstroende mot det politiska systemet kontrolleras också för respondenternas inställning till det demokratiska systemet. Frågan i Survey 2012 lyder: ”Om du tänker på det demokratiska systemet, hur väl anser du att det fungerar?” och variabeln har kodats om så att den bara antar två värden (1=mycket/ ganska dåligt; 0 =mycket/ganska bra). Ytterligare en kontroll är respondenternas generella inställning i vänster-höger frågor. I artikeln används en "objektiv" vänster-högerskala som baseras på ett genomsnittligt additivt index (Cronbachs alfa=0,667), där en rad frågor som har starkt samband med vänster-högerskalan har slagits samman: minska den offentliga sektorn, sänk skatterna, satsa på tillväxt, även om det innebär ökade skillnader. I likhet med tidigare frågor sträcker sig svarsalternativen mellan (1) "mycket bra" till (5) "mycket dåligt”, där (3) är "varken bra eller dåligt”. För att underlätta jämförelser transformeras också denna variabel så att den varierar mellan 0 och 10 .

Frågeställning 1: Hur pass generell är svenskarnas tillit?

Artikelns teoretiska utgångspunkt gör gällande att respondenters tillit för "människor i allmänhet” beror på räckvidden av deras föreställda gemenskaper. Mot den bakgrunden är den första frågeställningen om generell tillit i själva verket är ett mått på tillit till människor från närliggande kulturella sfärer (det som jag kallar ingruppen). Resultat i tabell 2 - som bygger på en faktoranalys - ger starka indikationer på att så är fallet i den svenska befolkningen. 
Tabell 2. Faktoranalys över tillit och två extraherade faktorer som mäter tillit för ut- och ingruppen.

\begin{tabular}{lcc}
\hline & Faktor 1. Tillit till utgrupper & $\begin{array}{c}\text { Faktor 2. Tillit till ingrupper } \\
\text { och generell tillit }\end{array}$ \\
\hline Människor från Mellanöstern & $\mathbf{0 , 9 1 9}$ & 0,249 \\
Människor från Afrika & $\mathbf{0 , 9 0 8}$ & 0,290 \\
Människor från Östeuropa & $\mathbf{0 , 8 6 1}$ & 0,328 \\
Människor från Latinamerika & $\mathbf{0 , 8 5 0}$ & 0,345 \\
Människor från min kommun & 0,183 & $\mathbf{0 , 9 2 2}$ \\
Människor från Sverige & 0,267 & $\mathbf{0 , 9 1 4}$ \\
Människor från Västeuropa & 0,456 & $\mathbf{0 , 7 8 0}$ \\
Människor i allmänhet $^{a}$ & 0,358 & $\mathbf{0 , 6 6 1}$ \\
\hline
\end{tabular}

Kommentar: Tabellen visar den roterade faktorlösningen (rotationsmetod: Varimax). Faktorladdningar över 0,5 är markerade med fetstil. Om istället en trefaktorlösning tillåts så formar generell tillit en egen dimension medan de två föregående kvarstår.

${ }^{a}$ Avser frågan som beskrivs i figur 1.

I linje med teoretiska förväntningar ger faktoranalysen i tabell 2 klara belägg för att tillit bland svenskar är beroende av "förtroendeobjektets” föreställda närhet eller distans till respondenters upplevda identitet och kulturella gemenskap. Med andra ord tenderar respondenternas grad av tillit att variera beroende på vilka grupper som frågan specificerar (Nannestad 2008). Min bedömning är att den första faktorn - det som kallas tillit till utgrupper - visar att det finns en distinkt underliggande dimension som rör tillit till människor från kulturella sfärer, som uppfattas vara avlägsna från den svenska. I motsats till tidigare forskning, där generell tillit något slentrianmässigt beskrivs som tillit för främlingar i största allmänhet - också tillit till människor av annan nationalitet och religionstillhörighet (Delhey m.fl. 2011:791) - visar faktoranalysen att det klassiska måttet på generell tillit laddar svagare på den faktor jag kallar tillit till utgrupper. Detta indikerar att svenskar inte primärt tänker på personer från Mellanöstern, Afrika, Östeuropa eller Latinamerika när de ombeds gradera sin tillit till människor i allmänhet. Istället visar den andra underliggande dimensionen att generell tillit - som antas mäta tilltro till okända människor i största allmänhet - i högre grad kopplas samman med grupper från samma eller närliggande kulturella sfärer som de flesta respondenter i urvalet - människor från samma kommun, land eller andra länder i Västeuropa. I tabell 3 korreleras de åtta måtten på tillit och resultaten ger ytterligare belägg för att de mäter ganska skiftande attityder. 
Tabell 3. Samvariation mellan olika mått på tillit (Pearsons $r$ ).

\begin{tabular}{|c|c|c|c|c|c|c|c|c|}
\hline & A & B & C & $\mathrm{D}$ & E & $\mathrm{F}$ & $\mathrm{G}$ & $\mathrm{H}$ \\
\hline $\begin{array}{l}\text { A. Människor från } \\
\text { Mellanöstern }\end{array}$ & 1 & 0.885* & $0.826^{*}$ & $0.817^{*}$ & $0.398 *$ & $0.454^{*}$ & $0.586^{*}$ & $0.448^{*}$ \\
\hline $\begin{array}{l}\text { B. Människor från } \\
\text { Afrika }\end{array}$ & & 1 & 0.836* & $0.844 *$ & $0.454^{*}$ & $0.517 *$ & $0.608^{*}$ & $0.497 *$ \\
\hline $\begin{array}{l}\text { C. Människor från } \\
\text { Östeuropa }\end{array}$ & & & 1 & $0.778^{*}$ & 0.499* & $0.517^{*}$ & $0.644^{*}$ & $0.452^{*}$ \\
\hline $\begin{array}{l}\text { D. Människor från } \\
\text { Latinamerika }\end{array}$ & & & & 1 & $0.469 *$ & $0.556^{*}$ & $0.638^{*}$ & $0.474^{*}$ \\
\hline $\begin{array}{l}\text { E. Människor från min } \\
\text { kommun }\end{array}$ & & & & & 1 & $0.879 *$ & 0.739* & $0.514^{*}$ \\
\hline $\begin{array}{l}\text { F. Människor från } \\
\text { Sverige }\end{array}$ & & & & & & 1 & 0.790* & $0.578^{*}$ \\
\hline $\begin{array}{l}\text { G. Människor från } \\
\text { Västeuropa }\end{array}$ & & & & & & & 1 & $0.570^{*}$ \\
\hline $\begin{array}{l}\text { H. Människor i } \\
\text { allmänhet }\end{array}$ & & & & & & & & 1 \\
\hline
\end{tabular}

Kommentar: I tabell 3 redovisas sambandsmåttet Pearsons $r$ som varierar mellan -1 (perfekt negativt samband) och +1 (perfekt positivt samband), där 0 visar frånvaro av samband.

Statistisk signifikans: $*=p<0,05$

Resultaten av korrelationssanalysen i tabell 3 nyanserar resultaten från faktoranalysen och fördjupar samtidigt insikten att tillit, och således respondenters föreställningar om vad som kännetecknar människor i allmänhet, beror på vilken kulturell grupp som står i fokus från enkätfrågan. I tabell 3 framgår emellertid att generell tillit - alltså tillit till människor i allmänhet - uppvisar förhållandevis låg samvariation med de andra sju måtten, vilket tyder på att variabeln är en distinkt dimension, som bör behandlas separat. Om vi godtar denna utgångspunkt har vi alltså att göra med tre distinkta dimensioner av tillit i den svenska befolkningen. Hur vanligt är det då att svenskar hyser tillit till vad de uppfattar som människor i allmänhet samt de olika grupper av människor som fångas upp av de två indexen? För att undersöka detta jämförs de olika måttens fördelning i figur 3.

Resultaten i figur 3 belyser återigen att tillit bland svenskar till stor del är en attityd som varierar beroende på vilka grupper av människor som frågorna avser. Andelen svarande som uppger sig lita på människor som inte är av svensk och västerländsk härkomst, som kan antas tillhöra deras utgrupp, är avsevärt mycket lägre än de som uppger sig lita på människor i allmänhet eller människor som tillhör samma upplevda kulturella sfär (det jag kallar ingrupp). Precis som faktoranalysen i tabell 2 visar också fördelningen i figur 3 att variabeln "generell tillit” fördelar sig på ett liknande sätt som variabeln som kallas ingruppstillit. Jag menar därför att resultaten i figur 3 ger en stark indikation om att tillit för människor i allmänhet i högre grad mäter tilltro till människor från samma kulturella 
sfär än människor med rötter utanför denna sfär. Med andra ord tycks inte generell tillit vara en fullt så generaliserande attityd som vi gärna tror.

Figur 3. Fördelning av tre tillitsmått i Survey 2012 (procent).

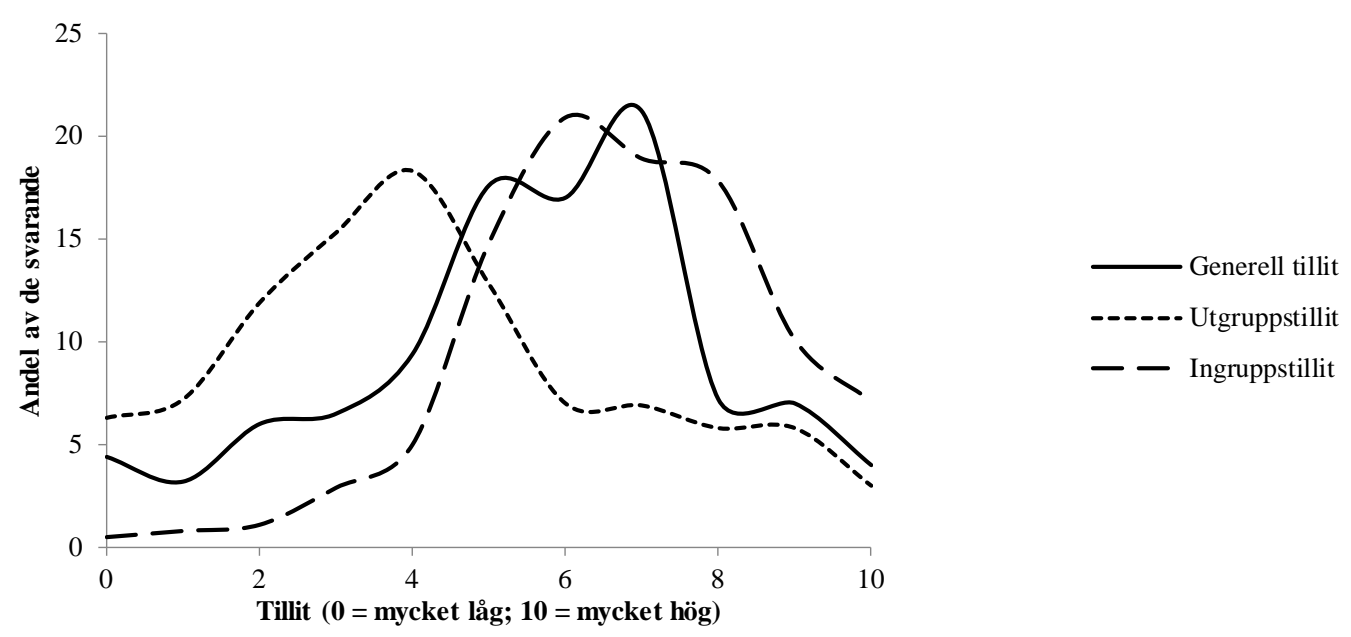

Kommentar: För frågan som avser generell tillit var antalet svarande 1500. För de övriga två är bortfallen avsevärda. För utgruppstillit är antalet svarande som uppgav sig ha en åsikt 1060 medan de för ingruppstillit är 1177.

Att det jag kallar utgruppstillit mäter något annat än tillit till människor i allmänhet stärks också av att denna variabel fördelar sig på ungefär samma sätt som variabeln som specifikt indikerar främlingstolerans.

Figur 4. Fördelning av utgruppstillit och främlingstolerans i Survey 2012 (procent).

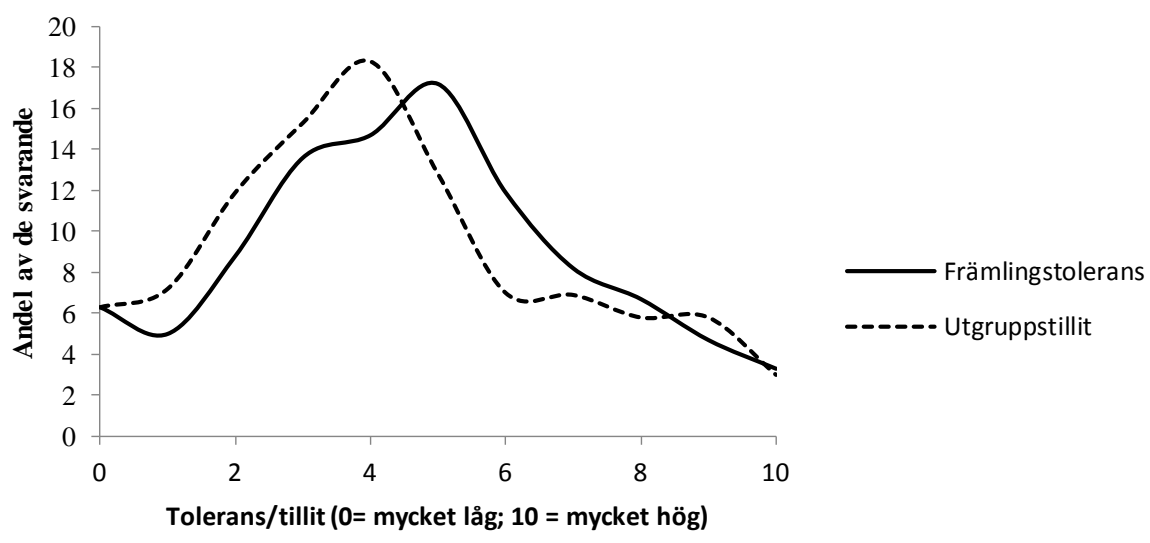

Kommentar: Antalet svarande för variabeln Främlingstolerans är 1520. 
Resultaten i figur 4, som visar en snarlik fördelning för de två variablerna, främlingstolerans och utgruppstillit, kan tyda på att tolerans eller intolerans mot främlingar mäter likartade attityder som upplevd tillit till dessa grupper. Denna misstanke stärks av att samvariationen mellan dessa variabler är stark $(r=0,578$, $p<0,01$ ), samtidigt som korrelationen är mycket svagare om vi jämför främlingstolerans med de andra två måtten på tillit (generell tillit: $r=0,330, p<0,01$; ingruppstillit: $r=0,261$, $p<0,01)$.

För att återkoppla till den första frågeställningen kan de sammanvägda resultaten hittills tolkas som att tillit i svensk opinion är uppdelad i två dimensioner: en som rör avlägsna främlingar och en som rör mindre avlägsna främlingar.

Frågeställning 2: Varierar tillit och tolerans om vi beaktar partisympati?

När vi nu har fått en inblick i svenska folkets övergripande nivåer av tillit och tolerans är frågan om sådana attityder relaterar till övriga politiska attityder, som kan sägas vara representerade av de olika partierna i det svenska partisystemet. För att ge ett preliminärt svar på denna andra frågeställning redovisar figur 5 resultaten från två medelvärdesanalyser där först ingrupps- och utgruppstillit och sedan utgruppstillit och främlingstolerans ställs i relation till de partisympatier, som uppges av respondenterna.

I den vänstra grafen i figur 5, där ut- och ingruppstillit studeras i relation till partisympati, framgår det att alla partisympatisörer ligger över skalans mittpunkt när det handlar om tillit till ingruppen, det vill säga människor från Sverige och Västeuropa (medelvärdet på denna skala är 6.8 och medianen är 7). Samtidigt hamnar de stora väljargrupperna (S och $\mathrm{M}$ ), inklusive SD:s sympatisörer, under skalans mittpunkt när det handlar om tillit till människor med rötter utanför Sverige och Västeuropa (medelvärdet på denna skala är 4.58 och medianen är 4.5). Snarlika resultat framkommer i den högra figuren där det visar sig att majoriteten av väljarkåren (dvs. S och $\mathrm{M}$ samt SD), hamnar under toleransskalans mittpunkt. Resultatet tyder således på att det finns en ganska utbredd intolerans i den svenska väljarkåren precis som i övriga europeiska länder (Mudde 2010). 


\section{Figur 5. Tillits- och toleransnivåer bland svenskar efter partisympati (medelvärde).}

Utgrupps- (vertikal) och ingruppstillit (horisontell)
Utgruppstillit (vertikal) och främlingstolerans (horisontell)
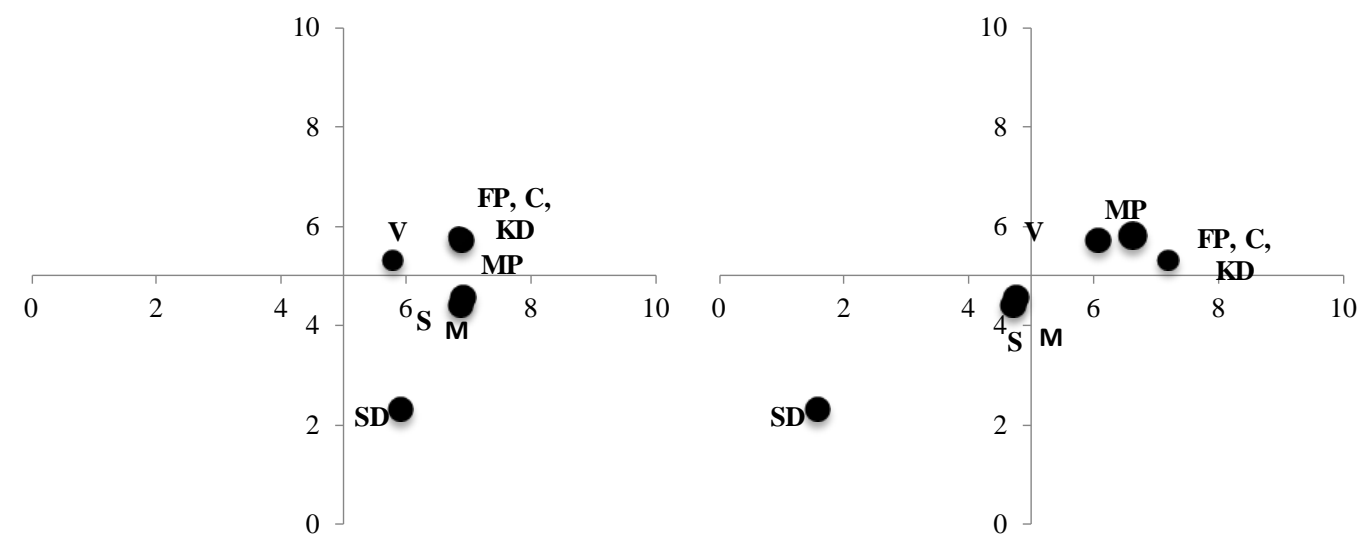

Kommentar: I den vänstra grafen mäts ingruppstillit på den horisontella axeln och utgruppstillit på den vertikala axeln (för båda skalorna är 0 = lägst tillit och 10 = högst tillit). I den högra grafen mäts utgruppstillit istället fortfarande på den vertikala axeln medan den horisontella nu visar genomsnitten för variabeln främlingstolerans ( 0 = låg tolerans och 10 = hög tolerans). I den vänstra grafen är skillnaderna i medelvärde, enligt Anova-test, för utgruppstillit, statistiskt signifikanta mellan M, S och SD och alla övriga $(p<0.01)$, och medelvärdet för SD-sympatisörer är signifikant skiljt från motsvarande värde för alla övriga partisympatisörer. När det gäller ingruppstillit är det endast det lägre medelvärdet för SD som är signifikant skiljt från övriga $(p<0.01)$. När det gäller variabeln främlingstolerans är återigen SD:S medelvärde statistiskt skiljt från alla övriga grupper $(p<0.01)$. Vad beträffar medelvärdena för M och S är dessa bara statistiskt signifikant skilda från motsvarande värden för SD, MP och V $(p<0.01)$ Samma sak gäller mittenpartierna (C, FP och $\mathrm{KD}$ ), vars medelvärde beräknats gemensamt och endast är statistiskt signifikant skiljt ifrån V, MP och SD $(p<0.01)$.

$\mathrm{M}=$ Moderaterna, $\mathrm{FP}=$ Folkpartiet, $\mathrm{C}=$ Centerpartiet, $\mathrm{KD}=$ Kristdemokraterna, $\mathrm{MP}=$ Miljöpartiet, $\mathrm{S}=$ Socialdemokraterna, $\mathrm{V}=$ Vänsterpartiet, $\mathrm{SD}=$ Sverigedemokraterna.

För att sammantaget återkoppla till artikelns två första frågeställningar har jag hittills visat att intolerans i hög grad går hand i hand med bristande tillit till främlingar från mer avlägsna kulturella sfärer. Resultaten visar alltså att det är fullt möjligt för svenskar att ge uttryck för tillit och bristande tolerans, det vill säga misstro, på samma gång. 
Frågeställning 3: Finns det en koppling mellan tillit och tolerans?

Vi har nu kommit till artikelns tredje och sista frågeställning som går ut på att belysa om, och i vilken grad, generell tillit, samt tillit till olika grupper av människor, påverkar tolerans eller intolerans mot främlingar. I tidigare forskning antar man ofta att höga nivåer av tillit borde motverka intolerans och främlingsrädsla i Sverige (se t.ex. Loxbo 2010a). Resultaten hittills visar dock att en sådan slutsats bör nyanseras. För att göra detta är uppgiften i det följande att undersöka i vad mån tillit i de tre dimensioner som har presenterats påverkar respondenternas tolerans eller intolerans inför främlingar. I tabell 4 redovisas tre bivariata regressionsanalyser, där effekten av de tre tillitsvariablerna på den beroende variabeln främlingstolerans undersöks var för sig.

Tabell 4. Effekter av tre mått på tillit på främlingstolerans. Resultat från bivariata linjära regressionsanalyser.

\begin{tabular}{lllllll}
\hline Oberoende variabler & $\alpha$ & $\mathrm{SE}_{\alpha}$ & $b$ & $\mathrm{SE}_{b}$ & $R^{2}$ & $\begin{array}{l}\text { Antal } \\
\text { observationer }\end{array}$ \\
\hline Utgruppstillit & $1,933^{* * *}$ & 0,134 & $0,584^{* * *}$ & 0,025 & 0,33 & 1053 \\
Ingruppstillit & $2,324 * * *$ & 0,259 & $0,338^{* * *}$ & 0,037 & 0,07 & 1166 \\
Generell tillit & $2,867 * * *$ & 0,154 & $0,361^{* * *}$ & 0,027 & 0,11 & 1483 \\
\hline
\end{tabular}

Kommentar: Tabellen redovisar ostandardiserade regressionskoefficienter ( $a$ respektive $b$ ) jämte standardfel ( $\mathrm{SE}_{\alpha}$ respektive $\mathrm{SE}_{b}$ ) och andel förklarad varians $\left(R^{2}\right)$. Vad gäller variablerna ut- och ingruppstillit är bortfallen ganska omfattande. Trots detta är båda dessa variabler approximativt normalfördelade.

Statistisk signifikans: $* * *=p<0,01$

Resultaten från de bivariata regressionsanalyserna i tabell 4 visar att alla mått på tillit har stark effekt på graden av främlingstolerans. I linje med resultaten från figur 4 ovan framgår det dock att utgruppstillit har starkast effekt när variablerna undersöks bivariat. För varje steg mot fullständig tillit för människor från utgruppen på skalan 0-10 ökar främlingstolerans med knappt 0,6 skalsteg, det vill säga 6 procentenheter. Det innebär att effekten av ökad utgruppstillit, vid bivariata jämförelser, är ungefär dubbelt så stor som effekten av ökad generell tillit eller ingruppstillit. Den förklarade variansen $\left(R^{2}\right)$ är hela 0,33 för denna variabel, vilket innebär att 33 procent av variationen i svenskarnas tolerans mot främlingar statistiskt sett kan förklaras av deras grad av tillit till människor från mer avlägsna kulturer - Mellanöstern, Afrika, Latinamerika och Östeuropa. Motsvarande förklaringsgrad för variabeln generell tillit är 11 procent medan nivån sjunker till 7 procent för variabeln ingruppstillit. Jag menar att dessa bivariata samband har två betydelsefulla implikationer. För det första kastar resultaten återigen en skugga över det utbredda antagandet att "tillit till människor i allmänhet” också mäter tillit till främlingar i allmänhet (se Nannestad 2008; Freitag \& Bauer 2013). För det andra tyder 
resultaten, trots de genomgående positiva effekterna av alla variabler, på att ett visst mått på tillit - för specifika grupper - kan existera sida vid sida med intolerans.

Hur håller då sambanden mellan de olika tillitsmåtten och främlingstolerans när de kontrolleras för en rad andra faktorer? För att svara på den frågan studeras robustheten i de tidigare sambanden med kontroll för en rad andra faktorer - som alla tros påverka tolerans mot främlingar i litteraturen - i en multivariat regressionsanalys i tabell 5 .

Tabell 5. Vad förklarar grad av främlingstolerans? Resultat från multivariata linjära regressionsanalyser.

\begin{tabular}{|c|c|c|c|c|c|c|}
\hline \multirow[t]{2}{*}{ Oberoende variabler } & \multicolumn{2}{|l|}{ Modell 1} & \multicolumn{2}{|l|}{ Modell 2} & \multicolumn{2}{|l|}{ Modell 3} \\
\hline & $b$ & $\mathrm{SE}_{b}$ & $b$ & $\mathrm{SE}_{b}$ & $b$ & $\mathrm{SE}_{b}$ \\
\hline Kvinna & $0,341 * * *$ & 0,132 & & & $0,238^{* *}$ & 0,135 \\
\hline Arbetare & $-0,833^{* * *}$ & 0,147 & & & $-0,600 * * *$ & 0,152 \\
\hline Invandrarbakgrund & 0,254 & 0,186 & & & $0,514 * * *$ & 0,186 \\
\hline Låg utbildning & $-1,743 * * *$ & 0,180 & & & $-0,675^{* * *}$ & 0,228 \\
\hline Medellåg utbildning & $-1,668 * * *$ & 0,156 & & & $-1,083^{* * *}$ & 0,185 \\
\hline Medelhög utbildning & $-1,063 * * *$ & 0,196 & & & $-0,597 * * *$ & 0,198 \\
\hline Hög utbildning (referenskategori) & 0,00 & & & & 0,00 & \\
\hline Systemmisstro & & & $-0,897 * * *$ & 0,168 & $-0,792^{* * *}$ & 0,170 \\
\hline Vänster-höger ståndpunkter & & & $-0,128 * * *$ & 0,030 & $-0,153^{* * *}$ & 0,031 \\
\hline Utgruppstillit & & & $0,569 * * *$ & 0,032 & $0,501 * * *$ & 0,034 \\
\hline Ingruppstillit & & & $-0,295 * * *$ & 0,047 & $-0,280 * * *$ & 0,048 \\
\hline Generell tillit & & & $0,211 * * *$ & 0,038 & $0,192 * * *$ & 0,039 \\
\hline Konstant & $6,017 * * *$ & 0,155 & $3,685^{* * *}$ & 0,310 & $4,730 * * *$ & 0,363 \\
\hline Justerat $R^{2}$ & 0,15 & & 0,40 & & 0,46 & \\
\hline Antal observationer & 1299 & & 1005 & & 961 & \\
\hline
\end{tabular}

Kommentar: Tabellen redovisar ostandardiserade regressionskoefficienter $(b)$ jämte standardfel $\left(\mathrm{SE}_{b}\right)$ och andel förklarad varians $\left(R^{2}\right)$. Vad gäller variablerna ut- och ingruppstillit är bortfallen ganska omfattande. Trots detta är båda dessa variabler approximativ normalfördelade. Eftersom sambandet mellan utbildning och tolerans är kurvlinjärt (i modell 3 är gruppen med medellåg utbildning minst toleranta) har jag använt dummy-variabler för att urskilja utbildningsnivåer. Referenskategorin i modell 1 och 3 är gruppen med hög utbildning, som då ställs i relation till de övriga tre grupperna.

Statistisk signifikans: $* * *=p<0,01 * *=p<0.05$ 
För att utföra kontrollerna har regressionsanalysen genomförts blockvis i tre steg. I modell 1 studeras endast sambanden mellan sociala bakgrundsfaktorer och främlingstolerans, medan modell 2 enbart fokuserar på effekterna av attitydvariabler, inklusive de tre måtten på tillit. I modell 3 studeras alla variabler med kontroll för varandra.

Resultaten i modell 1 är i hög grad förväntade och visar till att börja med att kvinnor i genomsnitt är mer främlingstoleranta än män. Därtill visar resultaten, också i linje med vad som kan förväntas, att människor med arbetarklassbakgrund i genomsnitt är mindre toleranta än övriga (ca 8 procentenheter) samt att lägre utbildningsnivå sammanfaller med lägre tolerans. Någon statistiskt signifikant effekt av invandrarbakgrund på tolerans är emellertid inte synlig i modell 1.

Om nu resultaten i modell 1 är i linje med vad som är känt sedan tidigare (se t.ex. Demker 2012; Demker \& Oscarsson 2012) menar jag emellertid att de som återfinns i modell 2 och, och särskilt i modell 3, sätter fingret på något nytt. I modell 2 framgår att alla mått på tillit har statistiskt signifikanta effekter med kontroll för systemmisstro och vänster-högeruppfattningar. Det framgår också att variablerna i modell 2 har avsevärt högre förklaringsgrad än variablerna i modell 1 (40 procent jämfört med 15 procent), vilket tyder på att främlingstolerans förklaras bättre av grundläggande attityder än av socioekonomisk bakgrund (Demker \& Oscarsson 2012). Den multivariata regressionsanalysen i modell 3 visar sedan att alla tillitsmått har positiva effekter på främlingstolerans också med kontroll för variabler som i litteraturen pekas ut som avgörande för främlingsfientlighet som politisk attityd (se t.ex. Loxbo 2010a; Loxbo 2010b). Vad som är särskilt intressant att notera i modellerna 2 och 3 är att för varje steg som ingruppstillit - dvs. tillit till svenskar och västeuropéer - ökar så minskar toleransen mot främlingar med runt en tredjedels steg på skalan 0-10 (det vill säga 3 procentenheters minskning per skalsteg). Den negativa effekten, som är statistiskt säkerställd till 99 procent, står i bjärt konstrast till resultaten från den bivariata analysen i tabell 4. Min tolkning av dessa förvånande, och omvända, resultat är att högre tillit till upplevda svenskar och västerlänningar - om övriga tillitsmått, vänster-högerideologi samt systemmisstro samtidigt kontrolleras för - faktiskt tycks vara negativt för tolerans. Samtidigt visar utgruppstillit samt generell tillit fortsatt positiva effekter i modell 2 och 3. För att besvara den tredje delfrågan är slutsatsen, att tillit på samma gång kan underbygga och motverka tolerans bland svenskar. Allt beror på vilken typ av tillit vi menar. Högre generell tillit och högre tillit till upplevda främlingar från utgruppen kan generera tolerans medan högre tillit till ingruppen snarare tycks sammanfalla med intolerans. 


\section{Slutsatser}

Sverige framhålls regelmässigt som ett land med exceptionellt hög tillit. Skrapar vi på ytan framträder dock en paradox. Den generella tilliten är stabilt hög i Sverige samtidigt som svensk opinion präglas av förhållandevis utbredd intolerans mot främlingar. I denna artikel studeras denna paradox och den vägledande problemställningen är om det möjligt för svenska folket att på samma gång uppge att de litar på "människor i allmänhet” och samtidigt uppvisa misstro, och till och med intolerans, mot människor som de upplever som främlingar. För att studera detta övergripande problem formulerades tre frågeställningar. Den första löd:

1. I vilken grad är generell tillit bland svenskar i själva verket ett mått på tillit till människor från närliggande kulturella sfärer?

Svaret på frågeställningen är kort och sammanfattningsvis att nivån på tillit tenderar att bero på räckvidden av vad som kan tolkas som respondenternas identitet och upplevda kulturella gemenskap (Putnam 2007; Nannestad 2008; Vroome m.fl. 2013:13). Annorlunda uttryckt tycks många svenskar primärt tänka på personer från Sverige och Västeuropa när de får frågor om sin tillit till människor i allmänhet. Resultaten indikerar således att respondenters grad av tillit beror på huruvida andra människor upplevs tillhöra deras in- och utgrupper. I motsats till tidigare forskning, som något slentrianmässigt beskriver generell tillit som tillit till främlingar i största allmänhet (Delhey m.fl. 2011:791) visar resultaten att tillit i hög grad tycks vara ett resultat av kulturella selektionsprocesser (Frietag \& Bauer 2013). Med andra ord tycks inte generell tillit - inte ens i det traditionellt tillitsfulla Sverige - vara en fullt så generaliserande attityd som vi gärna tror. Därför drar jag slutsatsen att "tillit till människor i allmänhet” inte framstår som ett särskilt träffsäkert mått på tillit till främlingar i allmänhet. Resultatet gäller emellertid svenska folkets attityder i genomsnitt och artikelns andra frågeställning tog fasta på om tillit för olika grupper och tolerans inför upplevda främlingar är relaterat till övriga politiska attityder, som på ett övergripande plan kan sägas vara representerade av partierna i det svenska partisystemet.

2. I vilken utsträckning varierar tillit och tolerans om vi samtidigt beaktar respondenternas sympati för olika politiska partier?

Som ett svar på denna frågeställning utgår resultaten från uppfattningar om tillit, i svensk väljaropinion, är uppdelad i två huvudsakliga dimensioner: en som rör tillit för avlägsna främlingar och en som rör mindre avlägsna främlingar. När dessa dimensioner sedan relateras till partisympatier bland väljarna framgår det att en majoritet av alla partisympatisörer uppger sig ha hög tillit till svenskar och västeuropéer medan en minoritet - endast mittenpartierna samt MP och V - rapporterar en hög grad av tillit till 
människor med utomvästliga kulturella rötter. Sammanfattningsvis, och för att återknyta till paradoxen som presenteras inledningsvis, visar resultaten att svenskar - genom att skilja på in- och utgrupper - kan vara tillitsfulla och misstroende på samma gång.

Den tredje frågeställningen tar sig mer explicit an paradoxen - att hög tillit och höga nivåer av främlingsintolerans tycks existera sida vid sida. Frågeställningen löd:

3. I vilken grad påverkar varierande, och gruppspecifika, mått på tillit graden av tolerans för upplevda främlingar från andra kulturer?

Svaret, som baseras på två regressionsanalyser, är att hög tillit inte nödvändigtvis är positivt för tolerans mot främlingar. Riktningen på sambandet beror i stället på huruvida vi mäter tillit för in- eller utgruppen. Med kontroll för en rad andra faktorer framkommer det nämligen, vilket är förvånande, att högre tillit till ingruppen upplevda svenskar och västerlänningar - faktiskt är kopplat till sjunkande tolerans mot vad som upplevs som främlingar. Samtidigt visar resultaten att högre utgruppstillit dvs. tillit till utomeuropéer - samt högre generell tillit bidrar till ökad tolerans. Jag menar att dessa resultat är förvånande och i hög grad pekar på värdet av att försöka urskilja olika typ mått när vi mäter tillit. Sammantaget ger mitt svar på den tredje frågeställningen också en förklaring till paradoxen som vägleder denna artikel; svenska befolkningen kan vara tillitsfulla och intoleranta på samma gång.

Avslutningsvis menar jag att resultaten i artikeln ger vidare implikationer för forskning om tillit och tolerans. Eftersom tillit antas vara en mycket seglivad attityd, som grundläggs tidigt i livet (Uslaner 2002, 2008), kan den starka kopplingen mellan utgruppstillit och främlingstolerans tyda på att den senare attityden, precis som tillit, är mer seglivad och svårföränderlig än tillfälliga politiska opinioner. Det kan i sin tur innebära att positiva eller negativa inställningar till invandring är mer seglivade och svårförändrade än vad många forskare har hoppats på (Demker 2012).

\section{Noter}

${ }^{1}$ I urvalet är 13,7 procent "första eller andra generationens invandrare” (baserat på uppgifter om respondentens och respondentens föräldrars huvudsakliga uppväxtland). Denna grupp uttrycker i genomsnitt högre toleransnivå än gruppen svenskfödda. Till detta kan läggas att gruppen invandrare inte kan antas ha samma in- respektive utgrupp som svenskfödda. Trots detta ingår denna grupp i det urval jag arbetar med, men variabeln införs sedan som kontroll i regressionsanalyserna. 


\section{Referenser:}

Bornschier, S. (2010): "The New Cultural Divide and the Two-Dimensional Space in Western Europe”, West European Politics 33 (3), 419-444.

http://dx.doi.org/10.1080/01402381003654387

Delhey, J, Newton, K., \& Welzel, C. (2011): "How General Is Trust in “Most People” Solving the Radius of Trust Problem”, American Sociological Review, 76:786-807.

Delhey, J. \& Newton, K.(2005): "Predicting Cross-National Levels of Social Trust: Global Pattern or Nordic Exceptionalism?”, European Sociological Review, Vol. 21, No. 4:311-327.

Demker, M. (2012): "Positiv attityd till invandring trots mobilisering av invandringsmotstånd”, i Weibull, L., Oscarsson, H., Bergström, A (red). I framtidens skugga. Göteborgs universitet: SOM-institutet.

De Vroome, T., Hooghe, M. \& Marien, S, (2013): “The Origins of Generalized and Political Trust among Immigrant Minorities and the Majority Population in the Netherlands”, European Sociological Review, 1-15. http://dx.doi.org/10.1093/esr/jct018

Frietag, M. \& Bauer, P.C. (2013): “Testing Measurement Equivalence in Surveys. Dimensions of Social Trust Across Cultural Contexts”, Public Opinion Quarterly 77:24-44.

http://dx.doi.org/10.1093/poq/nfs064

Hagevi, Magnus (2014): ”Survey 2012: Teknisk rapport”, Surveyjournalen 1(1):59-67.

Kumlin, S. \& Rothstein, B. (2010): “Questioning the New Liberal Dilemma: Immigrants,Social Networks, and Institutional Fairness”, Comparative Politics, 63-80.

http://dx.doi.org/10.5129/001041510X12911363510394

Loxbo, K. (2012): “Antisystemröstning”, i Hagevi, M (red.). Den svenska väljaren. Surveyinstitutet Volym 2, s. 165-181. Umeå: Boréa.

Loxbo, K. (2010a): 'Utmaningar mot det svenska partisystemet”, i Hagevi, Magnus (red). Avstamp. Svenska folkets värden och syn på brännande samhällsfrågor. Surveyinstitutet, volym 1. Växjö: Linnaeus University Press.

Loxbo, K. (2010b): "The impact of the Radical Right. Lessons from the Local Level in Sweden 2002-2006”, Scandinavian Political Studies 33 (3):295-315. http://dx.doi.org/10.1111/j.1467-9477.2010.00252.x

Mudde, C. (2010): “The Populist Radical Right: A Pathological Normalcy”, West European Politics 33 (6):1167-1186. http://dx.doi.org/10.1080/01402382.2010.508901

Nannestad, P. (2008): “What have we learned about generalized trust, if anything?”, The Annual Review of Political Science, 11, 413-436. 
Newton, K. (2001): “Trust, social capital, civil society, and democracy”, International Political Science Review, 22:201-214. http://dx.doi.org/10.1177/0192512101222004

Oscarsson, M., Demker, M., (2012): “Another kind of class voting. The working-class sympathy for Sweden Democrats”, i Rydgren, J, (red). Class Politics and the Radical Right. Routledge, London,171-189.

Putnam, R., (2007): "E Pluribus Unum: Diversity and Community in the Twenty-first Century: The 2006 Johan Skytte Prize Lecture”, Scandinavian Political Studies, Vol. 30, No. 2:137-174. http://dx.doi.org/10.1111/j.1467-9477.2007.00176.x

Stolle, D. (2002):“Trusting Strangers - the Concept of Generalized Trust in Perspective”, Österreichische Zeitschrift für Politikwissenschaft, 31: 4:397-412.

Uslaner, E. (2002): The Moral Foundations of Trust. Cambridge: Cambridge University Press.

Uslaner, E.(2008): "Where you stand depends upon where your grandparents sat: the inheritability of generalized trust”, Public Opinion Quarterly, Vol. 72, No. 4:725-740. http://dx.doi.org/10.1093/poq/nfn058

Wollebæk, D, Wallman Lundåsen, S., Trädgårdh, L.(2012): “Three Forms of Interpersonal Trust: Evidence from Swedish Municipalities”, Scandinavian Political Studies 35 (4), 319-346. http://dx.doi.org/10.1111/j.1467-9477.2012.00291.x

Yamagishi, T., \& Yamagishi M. (1994): “Trust and commitment in the United States and Japan”, Motivation and Emotion, 18:129-166. 